\title{
EFFECT OF FORGING SEQUENCE ON EVOLUTION OF PARAMETERS CONTROLLING MICROSTRUCTURE IN MULTISTAGE DROP FORGING PROCESS
}

\author{
SkUbisz Piotr* ${ }^{*}$ Lisiecki LUKASZ, JANUSz MAJTA, KRZYSZTOF MUSZKa \\ AGH University of Science and Technology, al. Mickiewicza 30, 30-059 Krakow, Poland \\ *Corresponding author: pskubisz@metal.agh.edu.pl
}

\begin{abstract}
The study presents the comparative analysis of competitive techniques of forging and analysis of the effect of the forging sequences on microstructure development. Starting with industrial practice of hammer-forged elongate geometry, two competitive processes were numerically analysed in term of forging economy and quality. Numerical modeling of temperature, strain and strain rate fields let theoretical prediction of the microstructure development in multi-stage drop forging process consisting of progressive sequence of multiple blows in preforming and die-impression forging operations. The aim of the modeling was prediction of the parameters of austenite in as-forged condition, which in thermomechanical controlled processing form the restored austenite condition prior to direct cooling. Dynamic recrystallization kinetics was analyzed with use of Johnson-Mehl-Avrami-Kolmogorov (JMAK) model, taking advantage of numerically calculated of temperature, strain and strain-rate in selected location in the volume of the part. The obtained results show the possibility of look-ahead microstructure prediction and form the basis for comprehensive selection of the forging process parameters aimed at producing required microstructure and its uniformity in the bulk in multi-stage hammer-forging process.
\end{abstract}

Key words: Drop forging, Thermomechanical processing, Microstructure evolution, Grain refinement

\section{INTRODUCTION}

Forging technology offers wide possibilities of shaping billet material to required geometry with an assumed accuracy (Takemasu et al., 1996). On account of technical difficulties in producing net shape, forged parts require number of allowances, including machining allowances, forging tolerance, mismatch and flash related surplus of material. Most material consuming is flash and allowances referring to its elimination, hence it is of big importance to optimize the forging process so as to minimize the flash. The flash is serious issue in forging elongate geometries, especially if the cross-sections vary a lot, or the longitudinal axis is either curved or fork-ended (Da Silva et al., 2006). Obviously, the flash is crucial for forging economy affecting material consumption, forging energy, tool life, and last but not least, costs of machining and heating up (Byrer et al., 1988).

Due to the necessity of considerable preforming, medium or small forging plants tend to produce such parts in drop forging process, owing to versatility of die-forging hammers. Forging technique for this kind of drop forgings often involves dozens of blows/strokes realized in several preforming operations. As a rule, individual part can be shaped in a number of competitive technological chains, including multi-stroke semi-open die preforming and impression forging which allow obtain the final part in different number of forging stages (Fujikawa, 2000; Skubisz et al., 2015). Abovementioned considerations are common as long as the forging yield and productivity rate are major components of forging economy balance (Werner, 1994). However, if the 
forging sequence is a part of thermomechanical controlled processing cycle, they must take into account deformation history and its aftermaths. In consideration of controlled cooling directly after forging, dynamic recrystallized austenite grain size and its distribution in the bulk is of primary importance (Mukherjee et al., 2014; Dhua \$ Sen, 2011; Kucera \& Mazancova, 2016), and so are the all intermediate stages of forging, which have critical impact on the microstructure inherited from run-out table austenite condition (Biba et al., 2006; Irani \& Taheri, 2008). Thus, influencing the forging conditions by variation of the forging sequence, machine employed and forging regime, allows controlling final microstructure and properties after thermomechanical processing (Adamczyk \& Opiela, 2006; Muszka et al., 2006).

The aim of the study is prediction of variation in microstructure parameters on the basis of comprehensive numerical simulation of a full processing chain, employing theoretical models of microstructure development. With a vast number of parts being forged in a hammer forging process, the question arises whether or not is the scatter in grain size after hammer forging sequence and its development during consecutive intermediate stages acceptable for utilization of direct controlled cooling with a view to produce uniform or controllable microstructure condition of deformed austenite before cooling. As the considered geometry is typical of many parts with head and shank, and the analyzed forging sequence is representative of conventional hammer forging process, which gives the results utilitarian meaning, as the theoretical modeling refers to technological limitations of the forging process.

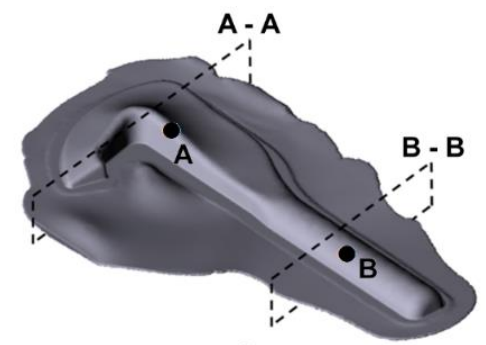

a)

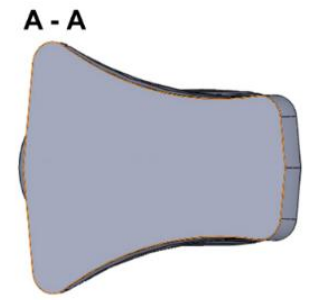

b)

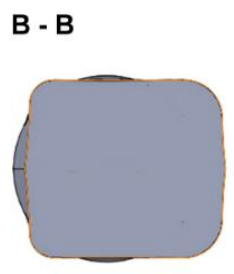

c)

Fig. 1 Forged geometry with location of the analysed cross-sections.

Table 1. Chemical composition of the microalloyed steel used in the study, wt. \%.

\begin{tabular}{|c|c|c|c|c|c|c|c|c|c|}
\hline $\mathrm{C}$ & $\mathrm{Mn}$ & $\mathrm{Cr}$ & $\mathrm{Si}$ & $\mathrm{Mo}$ & $\mathrm{Ti}$ & $\mathrm{V}$ & $\mathrm{Nb}$ & $\mathrm{N} p \mathrm{pm}$ & $\mathrm{Al}$ \\
\hline 0.30 & 1.50 & 0.42 & 0.26 & 0.01 & 0.011 & 0.09 & 0.039 & 110 & 0.039 \\
\hline
\end{tabular}




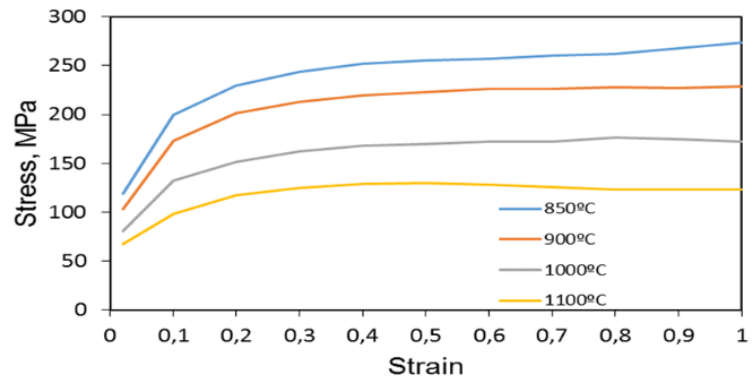

a)

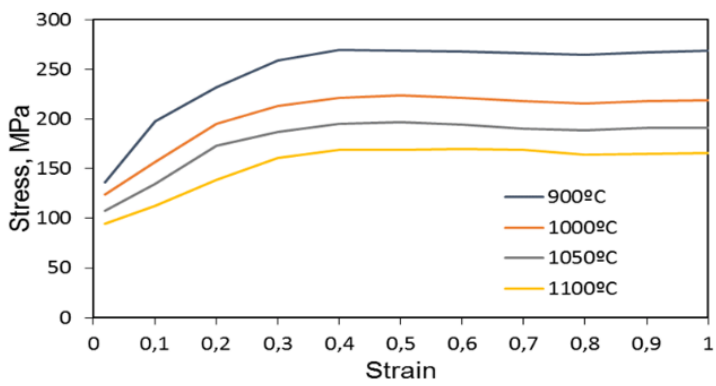

b)

Fig. 2. Flow curves obtained in compression test for: a) $5 s^{-1}$, b) $50 s^{-1}$.

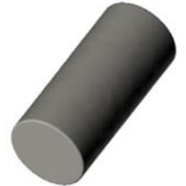

a)

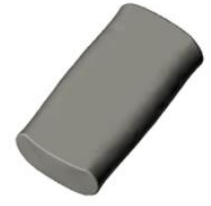

b)

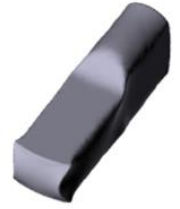

c)

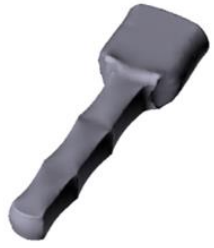

d)

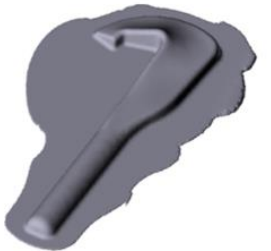

e)

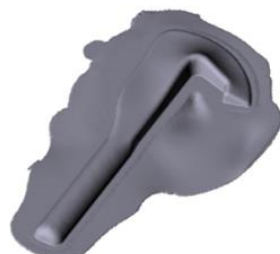

f)

Fig. 3. FEM modeling result of forging sequence I), where: a) billet, b) $\div$ d) hand-forge preforming, e),f) impression forging.

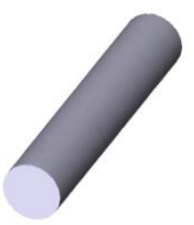

a)

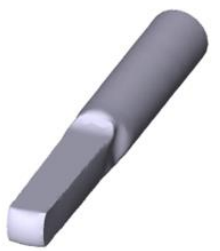

b)

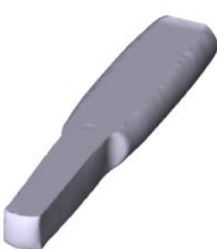

c)

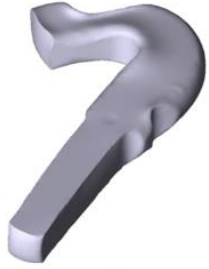

d)

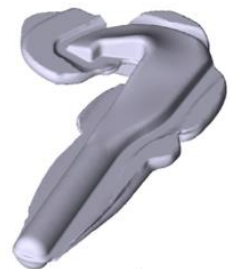

e)

Fig. 4. FEM modeling result of forging sequence II), where: a) billet, b) $\div$ d) hand-forge preforming, e) impression forging.

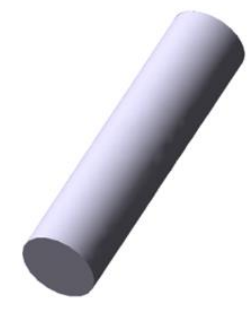

a)

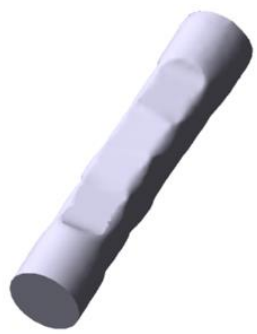

b)

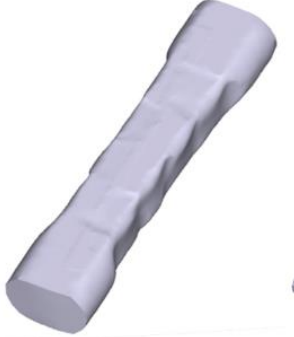

c)

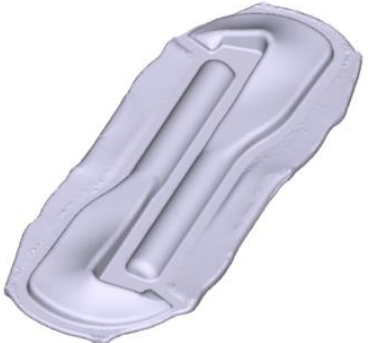

d)

Fig. 5. FEM modeling result of forging sequence III ), where: a) billet, b) $\div$ d) hand-forge preforming, e),f) impression forging.

\subsection{Theoretical background.}

In order to analyze the evolution of microstructure during consecutive forging operations, JMAK model based on classic theory of nucleation and grain growth was employed in the study, as the model which has been successfully used in modeling dynamic behavior of hot deformed microalloyed steels (Majta et al., 2002; Pietrzyk \& Madej, 2014). As far as the present demonstrative microalloyed steel is concerned, reliability of the model with regard to prediction of the microstructure changes during hammer forging of microalloyed steel is referred in related studies (Skubisz et al., 2017a; Skubisz et al., 2017b), where consistency to experimental measurements of the size of as-forged direct cooled ferrite-pearlite grains was assessed.

The analysis of microstructure evolution is based on the thermo-mechanical data derived from numerical modeling in selected points, representing two major sections of the part which were subject to different straining history, A and B in the center and on the surface. 
Calculation involved checking the condition of dynamic recrystallization occurrence, in accordance with the following criteria:

$$
\varepsilon_{c}=C \varepsilon_{p} \quad \varepsilon_{p}=B D_{0}^{m} Z^{p}
$$

where: $\varepsilon_{c}$ - threshold strain for dynamic recrystallization to occur, $\varepsilon_{p}$ - peak strain, $D_{0}$ - initial austenite grain size, $Z$-Zener-Hollomon parameter, $B, m, p-$ material constants.

The threshold strain level for $\mathrm{Nb}$-containing steel was calculated as:

$$
\begin{aligned}
& \varepsilon_{p}=\frac{1+20[\mathrm{Nb}]}{1.78} 2.8 \times 10^{-4} D_{0}^{0.5} Z^{p} \\
& \frac{\varepsilon_{c}}{\varepsilon_{p}}=0.8-11[\mathrm{Nb}]+117[\mathrm{Nb}]^{2}
\end{aligned}
$$

Activation energy for recystallization was defined on the basis of chemical composition with use of the formula:

$$
\begin{aligned}
Q= & 267-2.5[\mathrm{Mn}]+33.6[\mathrm{Si}]+35.6[\mathrm{Mo}] \\
& +70.7[\mathrm{Nb}]+93.7[\mathrm{Ti}]+31.6[\mathrm{~V}]
\end{aligned}
$$

Kinetics of dynamic recrystallization were calculated from JMAK equation:

$$
X=1-\exp \left[-0.693\left(\frac{\varepsilon-\varepsilon_{c}}{\varepsilon_{0.5}}\right)^{2}\right]
$$

where: $\varepsilon$ - unit deformation, $\varepsilon_{0.5}$ - amount of deformation needed for recrystallization of $50 \%$ of the volume under conditions considered.

Value $\varepsilon_{0.5}$ was calculated as:

$\varepsilon_{0.5}=1.114 \times 10^{-3} D_{0}^{0.25} \dot{\varepsilon}^{0.05} \exp \left(\frac{6420}{T}\right)$

where: $T$ - run out temperature.

Dynamically recrystallized austenite grain size was calculated as:

$$
D_{d x}=1.6 \times 10^{4} Z^{-0.23}
$$

and subsequent grain growth:

$$
D^{m}=D_{0}^{m}+k_{s} t \exp \left(\frac{Q_{g}}{R T}\right)
$$

where: $t$ - time after completion of recrystallization, $Q_{g}$ - grain growth activation energy.

\section{RESULTS OF MODELING}

Analysis of effect of forging technology on the quality of parts after controlled direct cooling, represented by microstructure evolution was conditioned by reliable simulation of multi-stage hammer forging process. Full consistency to real shape progression in the standard forging technology, as confirmed in related work (Skubisz et al., 2015), as well as agreement in temperature estimation, allowed assumption of reliability of taken boundary conditions for the key parameters in the proposed competing drop forging technologies.

The technology I, referred to as standard forging technique for this part, was analysed keeping the process parameters in accordance with industrial practice, e.g. forging temperature $1100^{\circ} \mathrm{C}$, number and sequence of blows. Competing modifications involved freely changed process conditions so as to produce attractive alternative for the standard process from a standpoint of material, energy and time consumption, as well as, minimization of gradients and differences within the part volume. Thus, feedstock dimensions and volume, intermediate operations, forging regime and blow energy was adapted accordingly within the range allowed by technical limitations, for example, due to shorter process, the forging temperature could be reduced to $1000^{\circ} \mathrm{C}$. The geometry evolution within these sequences is shown in figures $3 \div 5$.

To sum up the forging economy, major components of costs and benefits, which could be derived from FEM simulation, are listed in table 2, where yield is calculated as the volume of the forged part in relation to total volume of the workpiece, expressed in percent, and time sums up all forging, handling and dwell times within a single forging chain. As one could expect, bending offers best yield and the shortest process. However, in practice, thin billet results in process instability, which may lead to big number of rejected parts. Thus, sequence III, depending on multiple forging turns up the most reliable technology which offers attractive indices of production rate and reasonable yield. However, due to large volume of the billet it demands bigger capacity of press or higher number or energy of hammer blows.

Table 2. Comparison of components of forging economy for analysed technologies.

\begin{tabular}{|c|c|c|c|}
\hline & Yield & $\begin{array}{c}\text { Duration of the } \\
\text { process, s }\end{array}$ & $\begin{array}{c}\text { Number } \\
\text { of blows }\end{array}$ \\
\hline I & $78 \%$ & 28 & 13 to 16 \\
\hline II & $86 \%$ & 16 & 5 to 8 \\
\hline III & $83 \%$ & 16 & 8 to 10 \\
\hline
\end{tabular}

\subsection{Calculated stress fields in the forged part}

The key issue in the work was estimation of the temperature, strain and strain rate distribution 
throughout the forging sequences. Maps of the calculated distributions of the analysed parameters of use in modeling microstructure evolution are shown in figures 6 to 8 , for forging technology variants I-III, respectively. The results illustrate nonuniformity of strain in the bulk of the part, dependent on assumed forging technique, end thereby very strong effect of blow sequence on final strain and temperature fields.
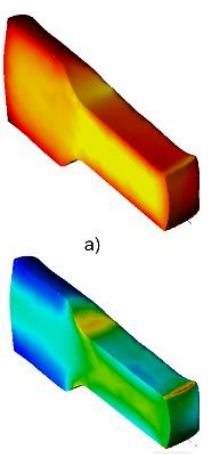

d)
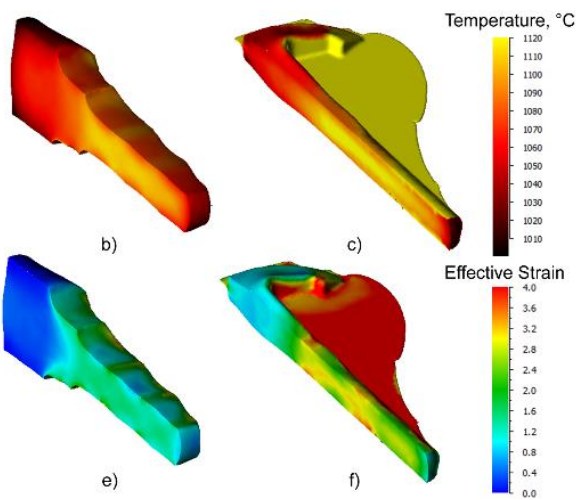

Fig. 6. FEM estimated maps of temperature (a-c) and effective strain in forging $(d-f)$ in forging sequence $I$.

In the most common technology, a sequence I (figure 6), the mass distribution is obtained through cogging, hence big discrepancy between hook (point A) and shank (point B) is observed. The same can be said about temperature gradients, however, temperature tends to equalize with finish-forge stage. As an alternative process, sequence II (figure 7), the initial strain is insignificant as due to bending transverse dimensions are closer. Thin billet results in lower strain values figure $7 \mathrm{a}-\mathrm{e}$ ), as well as, faster cooling (figure 7f). The low strain amount is inherited to the last impression, remaining relatively low. However, it is sufficient for refining recrystallized grain in both sections. As the process based on bending is shorter, despite smaller cross-section of the billet, cooling either, has no adverse effect. The most promising technique is offered by sequence III, where, in addition to best yield, also strain is distributed most uniformly in the bulk with reaching considerable amount of work (figure $8 \mathrm{a}$-c). Also temperature appear uniform, producing exit temperature, proper for direct cooling (figure $8 \mathrm{a}-\mathrm{c}$ ). Although it reaches the highest of all three variants, the temperature is associated with the highest amount of strain among all the three processes, which according to the JMAK model suffices to produce satisfactory refinement of austenite.

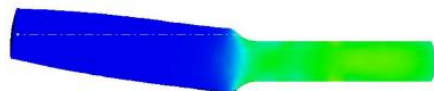

a)

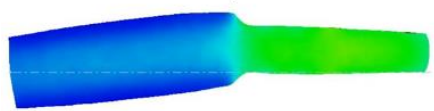

b)

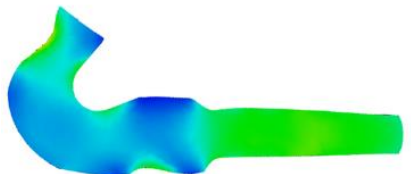

c)

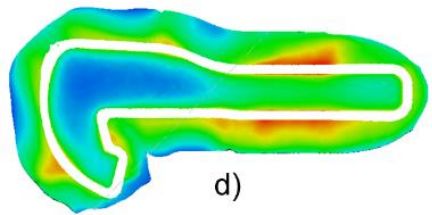

Effective Strain

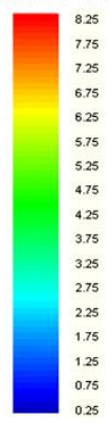

d)

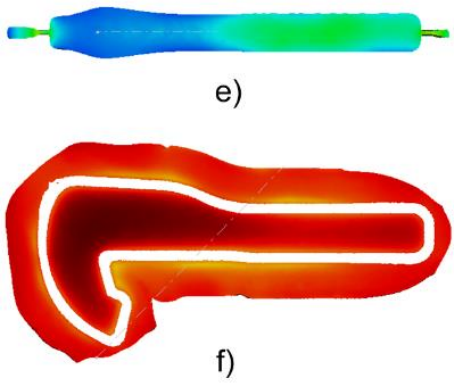

Temperature, ${ }^{\circ} \mathrm{C}$

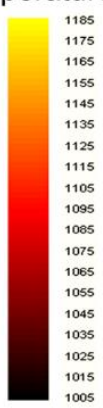

Fig. 7. FEM estimated maps of effective strain $(a \div e)$ and temperature $(f)$ on longitudinal cross-section in parting plane in forging sequence II.

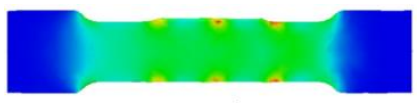

a)

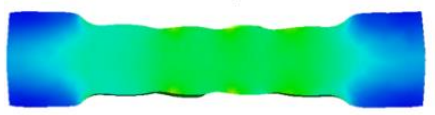

b)

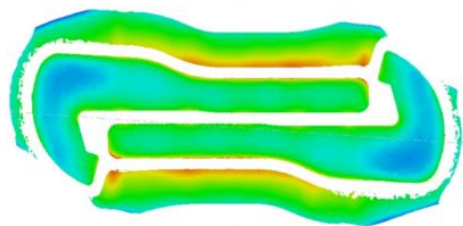

Effective Strain

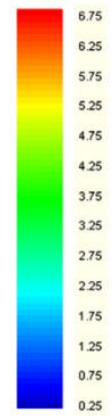

c)

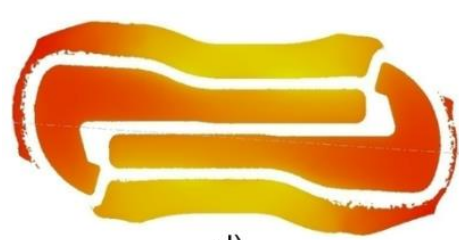

d)

Temperature, ${ }^{\circ} \mathrm{C}$

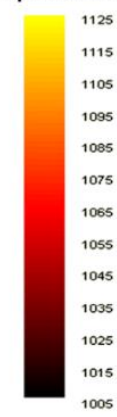

Fig. 8. FEM estimated maps of effective strain $(a \div c)$ and temperature $(d, e)$ on longitudinal cross-section $(e)$ and in parting plane $(d)$ in forging sequence II. 
To facilitate more insightful scope of all changes occurring during the whole forging sequence, the changes of the parameters have been summarized in plot shown in figure 9. The plot confirms observed differences, bringing in the time factor, which suggests that despite seemingly similar strain and temperature distribution, microstructure response can be different between forging variants. For instance, as compared to technology III characterized by the same strain, strain rate plot in variant II falls to zero (during bending). On the contrary, temperature variations are observed both on cross-section, between core and surface (figure 10a, b), and characteristic sections in the length, which is obvious especially for techniques I (figure 10a-b), and technique II (figure 10c), which is bound to have an impact in microstructure.

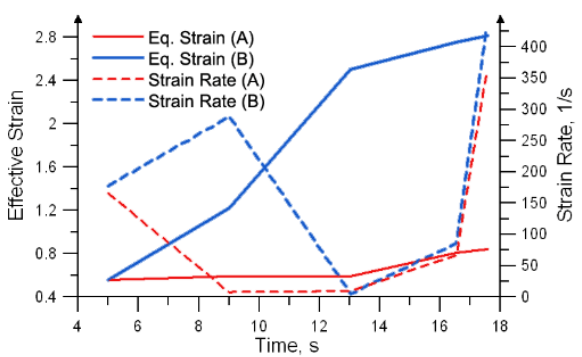

a)

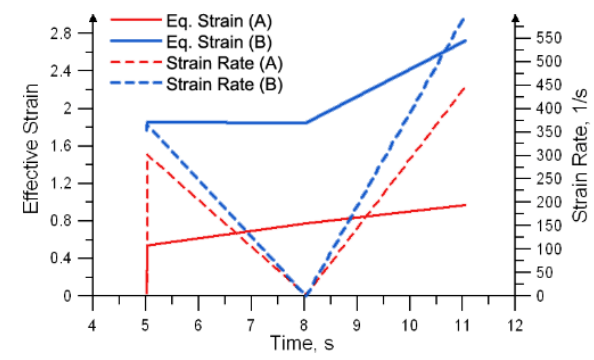

b)

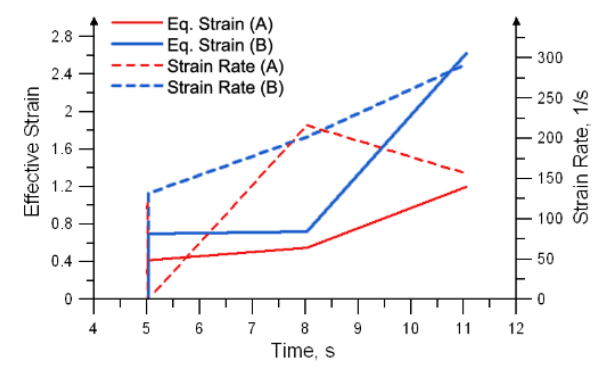

c)

Fig. 9. Plots of the FEM calculated equivalent strain and strain rate during hot forging in section A for: a) technology $I, b$ ) technology II, c) technology III.

\subsection{Comparative analysis of microstructure evolution.}

Thus, despite comparable total time of the whole deformation cycle and amount of deformation on the length, the differences in times between consecutive blows may cause differences in kinetics of grain structure restoration. It affect also rate of the process, as both recovery and recrystallization are diffusion driven phenomena and regardless of the variant, at this stage temperature is still very high (figure 10).

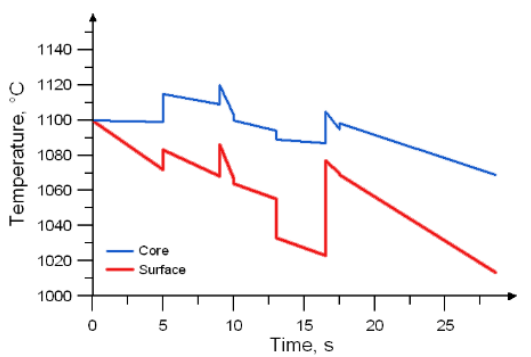

a)

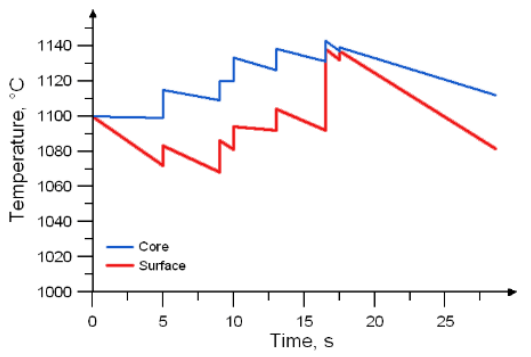

b)

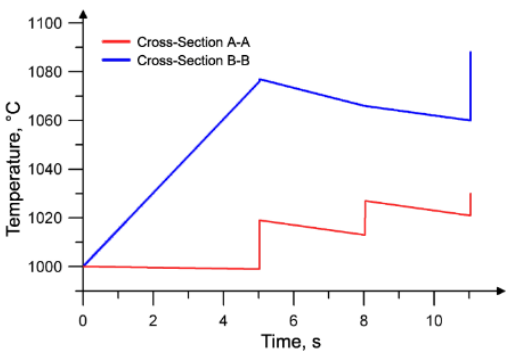

c)

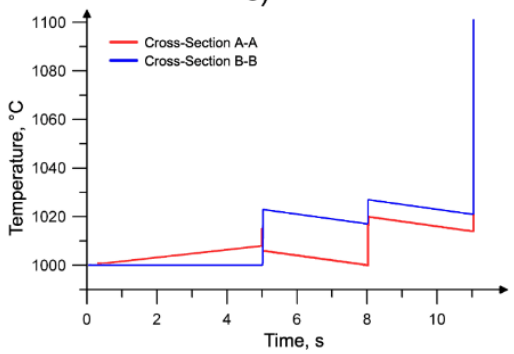

d)

Fig. 10. Plots of the FEM calculated temperature during hot forging in variants I section $A(a)$ and $B(b), I I$ and $I I$ (c, and d, respectively).

This dependence is well illustrated by comparative analysis of plots of equivalent strain history in point A and B (figure 9), and reflecting these variations in time, differences in grain size between the two sections in the axis of the part (viz, comparing figure 11 a) vs. b) for technology I; c) vs. d) for technology II and e) vs. f) for multiple forging in sequence III. In case of technology I the initial deformation covers the whole length preceding progressive sequence 
of small bites within future shank. This favours grain growth in the hook area until finish forge takes place (figure $11 \mathrm{a}, \mathrm{b}$ ). In addition to strain fluctuations on the length of the shank, the difference in strain enhances the mechanical nonuniformity contributing to local changes of flow stress. It leads to excessive stress gradients in the material subjected to deformation and adversely affect the performance under operating conditions (Fatemi \& Zoroufi, 2002). Somewhat similar sequence is observed in technology II, where initially flattened billet is elongated in cogging sequence and subject to bending, which brings no essential amount of work (figure $11 \mathrm{c}, \mathrm{d}$ ). In both cases the adverse effect of holding is eradicated by finisher impression forging.

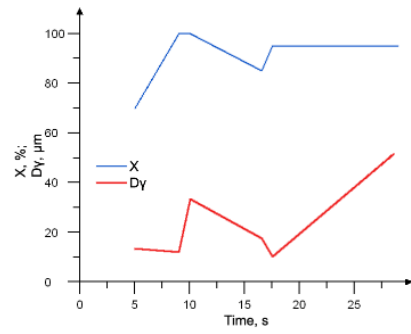

a)

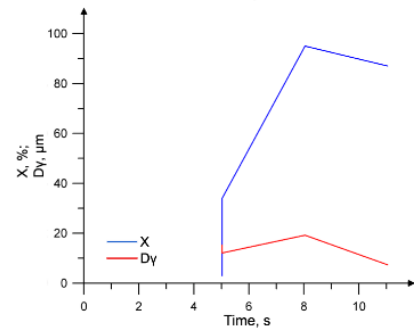

c)

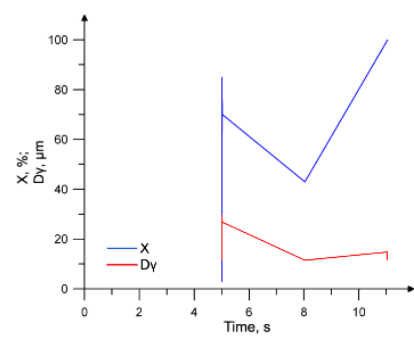

e)

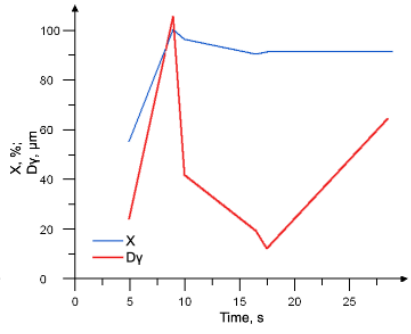

b)

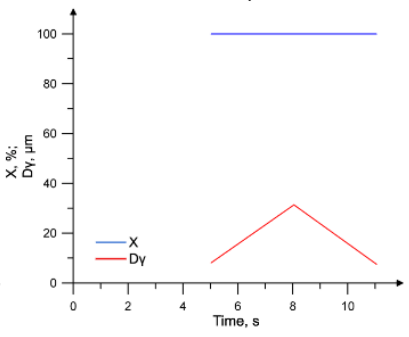

d)

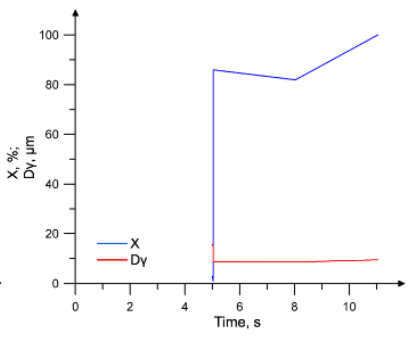

f)
Fig. 11. Results of mathematical modeling microstructure evolution during hot forging.

The evolution of microstructure in technology III is different. Large cross-sectional dimensions allow significant amount of work to be attained throughout the whole cycle, resulting in both moderate strain and strain rate, which favours grain refinement to obtain the lowest grain size amongst all compared variants. In combination with obvious material saving benefits, this makes this forging technique an attractive option for realization on hammers.

\section{CONCLUSIONS}

Presented study provides a comparative analysis of forging techniques available for shaping of an elongate part with bent axis. As indicated by FEM simulation, all the three proposed techniques are technically feasible to carry out on die-forging hammers, producing sound forgings without change in machining allowance. The forging sequence determine the economy of the process, in which of significance are yield and production rate indices. In both of these aspects technology II is superior to other ones, however, in forging practice technical considerations and quality aspects may make it too risky for the process stability.

One of the problems featuring processes of forging with consideration of direct cooling, eg. for microalloyed steels, is significant heterogeneity of the microstructure during the forging cycle, which enhances the mechanical nonuniformity related to local changes of flow stress. It leads to excessive stress gradients in the material subjected to deformation and adversely affect the performance under operating conditions. Numerical simulation indicates the effect of consecutive operations on final uniformity of strain and temperature gradients, which directly influence the transformation products after subsequent controlled cooling, regardless of expected structural composition.

Calculated differences in strain distribution and forge-end temperature gradients as well as microstructure nonuniformity resulting from employed forging sequence are significant, thus selection of the best forging technology should not involve merely economical consideration if direct cooling is to be applied. Since as-forged microstructure condition is inherited to products of austenite decomposition it is of great importance that stroke or blow sequence produce fine-grained structure prior to cooling.

Computer simulation with a use of reliable microstructure evolution models forms robust and timesaving tool for favorable forging technique to be selected. With a variety of elongate forgings with varying cross-section, the presented work can be of significance as a representative of forged parts similar in shape coefficient

\section{ACKNOWLEDGMENTS}

Financial assistance of NCBiR within project PBS2/B5/29/2013 (agr. 19.19.110.86730) is acknowledged. 


\section{REFERENCES}

Adamczyk, J., Opiela, M., 2006, Engineering of Forged Products of Microalloyed Constructional Steels, J. Arch. Mater. Manuf. Eng., 15, 153-158.

Biba, N.V., Stebunov, S.A., Ovchinnikov, A.V., Shmelev, V.P., 2006, Experience in simulation for predicting the structure of die forgings, Met. Sci. Heat Treat., 48, 7-8.

Byrer, T.G., Semiatin, S.L., Vollmer, D.C. (eds.), 1985, Forging Handbook, Forging Industry Association, American Society of Metals, Cleveland, 1985.

Da Silva, M.L.N., Regone, W., Button, S.T., 2006, Microstructure and mechanical properties of microalloyed steel forgings manufactured from cross-wedge-rolled preforms, Scripta Mater. 54, 213-217.

Dhua, S.K., Sen, S., 2011, Effect of direct quenching on the microstructure and mechanical properties of the lean chemistry HSLA-100 steel plates, Mat. Sci. Eng. A, 528, 6356-6365.

Fatemi, A., Zoroufi, M., 2002, Fatigue performance evaluation of forged versus competing process technologies: a comparative study. Proc. 24th Forging Industry Technical Conference, Cleveland, 2002.

Fujikawa, S., 2000, Application of CAE for hot-forging of automotive components, J. Mater. Proc. Tech., 98, 176-181.

Irani, M., Taheri, A.K., 2008, Effect of forging temperature on homogeneity of microstructure and hardness of precision forged steel spur gear, Mater. Chem. Phys, 112, 3, 10991105.

Kučera, P., Mazancova, E., 2016, Mechanical and structural response of AISI 4135 steel after controlled cooling process, Metalurgija, 55(2), 165-168.

Muszka, K., Majta, J., Bienias, L., 2006, Effect of grain refinement on mechanical properties of microalloyed steels, Met. Foundry Eng., 32, 87-96.

Majta, J; Zurek, A.K., Cola, M., Hochanadel, P., Pietrzyk, M., 2002, An integrated computer model with applications for austenite-to-ferrite transformation during hot deformation of Nb-microalloyed steels, Metall. Mater. Trans. A, 33, 1509-1520.

Mukherjee, M., Prahl, U., Bleck, W., 2014, Modelling the straininduced precipitation kinetics of vanadium carbonitride during hot working of precipitation-hardened ferritic-pearlitic steels, Acta Mater., 71, 234-254.

Pietrzyk, M., Madej, Ł., 2014, perceptive review of ferrous micro/macro material models for thermo-mechanical processing applications, Steel Res. Int., 88(10), 1-14.

Skubisz, P., Micek, P., Sińczak, J., Tumidajewicz, M., 2011, Automated determination and on-line correction of emissivity coefficient in controlled cooling of drop forgings, Diffusion and Defect Data - Solid State Data. Part B, Sol. St. Phen., 177, 76-83.

Skubisz, P., Żak, A., Burdek, M., Lisiecki, Ł., Micek, P., 2015, Design of controlled processing conditions for drop forgings made of microalloy steel grades for mining industry. Arch. Metal. Mat., 60(1), 445-453.

Skubisz, P., Lisiecki, Ł., Majta, J., Muszka, K., 2017a, Modeling of microstructure development in multi-stage hammer forging and fan cooling of microalloyed steel, Metal 2017: 26th Int. Conf. on Metallurgy and Materials, Brno, 127-128.
Skubisz, P., Muszka, K., Lisiecki Ł., Majta, J., 2017b, Modelování vývoje mikrostruktury při víceoperačním kování mikrolegované oceli na bucharu a následném zrychleném ochlazování, Kovárenství, 62, 23-27.

Takemasu, T., Vasques, V., Painter, B., Altan, T., 1996, Investigation of metal flow and preform optimization in flashless forging of a connecting rod, J. Mater. Proc. Tech., 59, 95105 ,

Werner, W.A., (ed.), 1994, Schmiedeteile-Gestaltung. Anwendung, Beispiele, Zuverlassig Deutsche Schmiedetechnik, Hagen, 1994.

\section{WPLYW TECHNOLOGII NA ZMIANY PARAMETRÓW STERUJĄCYCH ROZWOJEM MIKROSTRUKTURY W PROCESIE WIELOZABIEGOWEGO KUCIA MATRYCOWEGO}

\section{Streszczenie}

W pracy przedstawiono analizę porównawczą trzech sposobów kucia wielowykrojowego, która obejmuje dwa aspekty: 1) wpływ technologii na wskaźniki techniczno-ekonomiczne i siłowo-energetyczne oraz 2) rozkład w objętości i zmiany w czasie parametrów termo-mechanicznych, wpływających na kinetykę zjawisk dynamicznych w odkształcanym materiale oraz jakość odkuwki. Na podstawie wyników modelowania numerycznego oceniono wpływ zmian w technologii kucia na rozkład odkształceń, prędkość odkształcenia oraz temperatury w reprezentatywnych przekrojach odkuwki. Na ich podstawie wykonano modelowanie rozwoju mikrostruktury, oparte o klasyczne modele zarodkowania i rozrostu ziarna podczas rekrystalizacji dynamicznej i przemiany dyfuzyjnej przechłodzonego austenitu w oparciu o model JMAK. Jak wskazują wyniki modelowania, zmiany sposobu lub warunków kucia matrycowego stwarzają możliwości istotnego oddziaływania na rozkład odkształceń i silnie wpływają na temperaturę w objętości okuwki. To z kolei, może być wykorzystane do zniwelowania niekorzystnego wpływu warunków odkształcania na mikrostrukturę lub jej poprawy.

Przedstawione wykresy pokazują istotne zmiany wielkości ziarna wraz z progresja odkształcenia $\mathrm{w}$ analizowanych punktach odkuwki. Jak widać, kształt odkuwki nie sprzyja uzyskaniu jednorodnego odkształcenia. Relatywnie małe odkształcenie podczas wstępnego spłaszczania pręta poprzedzający kilkunastosekundowy okres działania wysokiej temperatury, do momentu matrycowania, sprawia, że w obszarze zgrubienia prognozowane jest największe ziarno. Największe odkształcenie występuje w obszarze trzonu, jednakże sposób wstępnego kształtowania przedkuwki tego fragmentu odkuwki skutkuje przesunięciem w czasie odkształceń cząstkowych, przez co nawet na długości trzonu mogą wystapić zmiany mikrostruktury. Zróżnicowanemu odkształceniu w zgrubieniu oraz trzonie odkuwki towarzyszą duże różnice prędkości odkształcenia, co przekłada się na kumulację odkształcenia w czasie.

Analiza rozwoju mikrostruktury pozwala na odpowiednią korektę warunków kontrolowanego chłodzenia dla charakterystycznych fragmentów odkuwki, jak również odpowiednią korektę sekwencji i warunków realizacji kolejnych operacji kucia.

Received: October 7, 2019 Received in a revised form: December 10, 2019. Accepted: December 28, 2019. 